\title{
It's Alive! The Persistence of the Constitution
}

I must admit to being a fan of the "living dead" movies and their various progeny. ${ }^{1}$ Within the subgenre, the corpses of the dead are reanimated through the influence of contagion, radiation, or scientific intervention. These zombies then ravenously stalk the living, often creating a new generation of zombies in the process. Unlike the undead of the vampire mythos, the living dead are neither beautiful nor sophisticated. The living dead lumber through the landscape in an arrested state of decomposition, falling apart and clearly dysfunctional and yet somehow still ambulatory. Generally inarticulate and dimwitted, the living dead are guided by irrational hunger and consume the living. Having risen from their graves, the living dead crowd the scene, attacking en masse, filling every possible escape route, and blocking progress at every turn. In the movies, the dead hand of the past weighs very heavy indeed.

For some, the U.S. Constitution evokes similar nightmares. It shambles onward, completely out of its own context and barely coherent, and yet refusing to die. It imposes itself on the living, mindlessly closing off options and privileging its own unnatural priorities. James Madison and his brethren loom before us when they should be safely behind us. Through the instrument of the Constitution, the founders rule us from beyond the grave.

Are we terrorized by a tyranny of the dead? I do not believe that it is fruitful in either descriptive or normative terms to regard the written Constitution as a form of "temporal imperialism" that allows its authors to "dictate, even when their bodies are silent in death." ${ }^{\prime 2}$ In this essay, I want first to ameliorate the problem of the Constitution of the living dead and then to briefly defend an approach to constitutional interpretation that privileges original intent. Although the latter directs judges to look to the language and intentions of persons long dead, it does so out of respect for the living, not out of any special authority of the dead.

It should be emphasized that the Constitution is not quite the decrepit zombie that it is sometimes made out to be. We do not live with the same Constitution that was handed down by the founders in the late eighteenth century. Of course this is true in the obvious sense that the Constitution has been amended several times since the founding. Practices that we would no longer find tolerable, such as slavery and the exclusion of women from the political process, and infirmities that we are not willing to accept, such as (arguably) the absence of a federal income tax or the lack of clarity in presidential succession, have been eliminated over time in ways that are both explicit and perfectly consistent with the original constitutional design.

It is also true in a less obvious sense. Our constitutional system, as well as our constitutional text, looks very different than the one imagined by the framers. For one thing, the constitutional machinery did not work as they expected. Influenced by the republican political ideology of the time, for example, the founders were highly skeptical of the value of political parties or factions, and they hoped that the political system that they designed would discourage the growth of parties and limit their influence if they did arise. ${ }^{3}$ Instead, organized political factions arose almost immediately. There was no consensus over the ends and means of the public good, and organization proved an efficient mechanism for making policy and staffing the government. Similarly, the founders thought population growth would occur in the South rather than the North, enhancing the South's influence in the House of Representatives and securing political protection for its peculiar institution of slavery. ${ }^{4}$ Instead new citizens flowed into the free states of the North and Northwest. The South was increasingly isolated politically and increasingly reliant on countermajoritarian checks to protect its vital interests. Democracy and slavery, and therefore union, proved to be contradictory rather than mutually reinforcing. At the same time, the interest in both preserving and eliminating slavery became far more intense than the founders had imagined. Rather than being put on the path to gradual extinction, slavery became even more difficult to dislodge in the decades after the founding. The constitutional design failed to prevent discord, rupture, and war. In the aftermath of the Civil War, the constitutional system had to be redesigned and a key concern of the founders was discarded. 


\section{CONSTITUTION OF THE LIVING DEAD}

Other changes have been wrought within the confines of the original framework but in ways that the founders never foresaw. As John Marshall emphasized (perhaps overemphasized), the Constitution was intended for a growing nation and has a fair amount of flexibility to accommodate that growth. ${ }^{5}$ Changing circumstances and changing aspirations have led political actors to alter the constitutional system in ways that are fundamental and yet consistent with the terms of the founders' text. The founders' Constitution has been durable in part because it was built on the back of the state constitutions. When the states underwent constitutional revolutions, the federal constitutional text was relatively untouched, even though its operation was significantly modified. Though exceptionally democratic in historical terms, the constitutional system of the founders was still dominated by a social and political elite. Over time much more popular elements have been introduced into the system. Within decades of the founding, suffrage restrictions had been drastically eased and mass parties had been organized to mobilize popular participation in the government. Likewise, in the twentieth century, popular participation in the selection of political officials extended into the Senate and into the choice of party nominees. Eighteenth and nineteenth century battles over the power of formal instruction of representatives by their constituents have been supplanted by the rise of the far more effective vehicle of public opinion polling. The presidency grew from being a ceremonial figure and constitutional magistrate to being a popular leader and an important policymaker. The nation has grown from being an isolated republic to a global superpower, with the attendant military-industrial complex. We have accepted criminal and civil procedures that the founders undoubtedly would have found intolerable, while adopting others that they would have found utopian. Within a decade of living under the Constitution, the founding generation was already discovering that notion of free speech in a democracy had a life of its own that rendered some traditional government practices politically unbrookable. Alexander Hamilton argued that "the constitutional equilibrium between the general and State governments" was "left to the prudence and firmness of the people" but asserted that "the natural conclusion of such contests will be most apt to end to the disadvantage of the Union." But especially in the twentieth century Hamilton's "conjectures" proved to be quite "fallible," as the national government has proven more adept than the states in winning support from the people and expanding its own sphere of influence. ${ }^{6}$

The founders created a framework for government, and subsequent generations have constructed a living body around it. Although too much can be made of the biological metaphors favored by the Progressives, they were right to note that the Constitution is a living organism. Neither a Newtonian machine nor an animated corpse, the constitutional system is a common project constantly constructed and reconstructed by many hands across the generations. ${ }^{7}$ The founders have not left us a dusty mausoleum and insisted that we live within it. They have left us the old family home, which we rewire, remodel, and redecorate to make habitable and comfortable for us.

The problem of an inherited constitution can only be ameliorated not eliminated, however. The Constitution is not an empty shell, essentially contentless except for what we choose to add to it. The Constitution also imposes limits. We no longer particularly feel some of those limits, for we have outpaced them and have struggle with more salient limits of our own. Fortunately we have had no need to invoke the Third Amendment's ban on quartering troops in private homes, and we no longer even consider the types of punishments that the founders might have thought cruel and unusual. Even so, we still do feel the pinch of some of the framers' hand-

iwork. We sometimes would like to concentrate power that they dispersed. We sometimes seek to restrict liberties that they thought should be protected. We have sometimes wanted to use their text to trump our opponents whom we cannot overcome by other means. Must we adhere to the language and intentions of those long dead when it interferes with our current political desires?

The answer to that question depends on what we mean by "must." There is nothing that prevents us from throwing off the chains of the past, just as members of the founding generation threw off the yoke of empire and abandoned the Articles of Confederation and some of their descendents broke the shackles of slavery. We could bid farewell to the founders' text and draft a new one of our own, as the states have routinely done. We could preserve the Constitution of 1789 as a revered political symbol and source of inspiration, but abandon it as a governing document and supreme law. Rather than seek to commune with the spirits of the dead in order to resolve the bitter political disputes of the living, we could cease to interpret the 
Constitution and resolve our political differences on our own. We could even constitute a great and Supreme Court armed with a "prerogative" power to right wrongs, fight injustice, and practice random acts of kindness, but no longer speaking in the name of the law of the written Constitution. ${ }^{8}$ We could pursue our present heart's desires, and not worry about whether or not they are constitutional.

In the alternative, we could continue to adhere to the constitutional and judicial project to which we have claimed fidelity for more than two hundred years and seek to live within the confines of the Constitution as written. The implication of making that decision is that we must interpret the existing Constitution, which in turn necessitates adhering to the language and intentions of those long dead. In that case, the Constitution would not only or merely be a source of inspiration or guidance or foundation for our own constitutional constructions, but would be an object of judicial and political interpretation and a source of binding law.

I will not attempt to offer a full defense of this claim here. ${ }^{9}$ Let me instead simply sketch a reason why adhering to the intentions of the dead is justified in terms of the living. As the previous paragraphs indicate, the starting point for any such analysis is to recognize that the decision to interpret the written Constitution and be bound by the intentions of the founders is a present one, made by living political actors. It is not a decision that is or could be imposed on the present generation by the past. Unlike in a horror movie, James Madison cannot rise from his grave and force the hand of the living. If we defer to Madison, it is our choice.

There are three ways to resolve current political disagreements. We can somehow work it out ourselves, through majority rule, bargaining and compromise, deliberation and debate, and the like. We can delegate the decision to somebody else. To some degree we almost always delegate anyway, by electing and hiring representatives to hash out the nation's business in the capital while we get on with the more important business of living our lives. But "we" could choose to delegate our controversial political decisions to an even greater degree, throwing the issue into the lap of a "blue-ribbon commission," some executive administrator, or even the courts. We divest political discretion to some third party and live with the results. Finally, we can abide by decisions that have already been made, that is we can adhere to the existing law. Rather than revisit the controversy ourselves or trust the discretion of someone else, we simply defer to earlier judgments embodied in the law. Having made the decision to keep faith with the law, we may appoint someone to interpret and apply the law for us and keep things on an even keel until we are ready to revisit the issue..$^{10}$ We should recognize that the interpretive effort will require the exercise of some judgment, but we would, of course, expect the appointed interpreter not to exercise the discretion of a delegated decisionmaker.

The issue is what standard should be used to resolve contemporary political controversies and who should have the authority to make the resolution. Contemporary political actors are displaced by any judicial decision. If judges offer an interpretation of the text in accord with the language and intent of the founders, then those contemporary political actors have only deferred their right to make the choice themselves and remake the law. If judges do not offer such an interpretation, then we have simply replaced one relatively democratic set of contemporary decisionmakers with another much less democratic one. If judges interpret the originalist text, then the people retain their sovereign lawmaking authority to create, amend or replace the higher law. If judges do not, then the legislative power of the sovereign people would have been lost. The basic constitutional choices would be made by judges rather than by those who draft and ratify the constitutional text, whether those drafters and ratifiers did their work two hundred years ago or yesterday.

We privilege the intentions of the founders out of respect for the role of the constitutional founder, not out of respect for any particular founder. It is commonplace that we distinguish between the office and the officeholder, between institutional and personal authority. We respect the actions of the president and the Congress out of regard for the offices, not out of regard for the individuals who hold those offices. Likewise, those who drafted and ratified our present Constitution occupied a political role. It is a role that we do and should respect, not least because it is a role that we could ourselves play. It is true that we almost immediately began to cloak the founders in a more personal authority, developing a hagiography that emphasized their unique wisdom and a narrative of special dispensation for the founding generation from the usual forces of interest and passion. ${ }^{11}$ Although sometimes useful, such political myth-making can also be subversive of consensual constitutional governance and should certainly form no part of our current justification for adhering to the inherited Constitution. We should respect the substance of the constitutional choices of the founding not because the founders necessarily got it right, but because we should take seriously the idea of constitutional deliberation and founding as conscious, real-time political events. We should act so as to preserve the possibility of self-governance. 
It should be emphasized that the point of originalist constitutional interpretation is not to clear the way for current legislative majorities. ${ }^{12}$ Originalist judges are not necessarily deferential judges. It may well be the case that the originalist Constitution has little of substance to say about current political controversies. The Constitution may not require anything in particular in regards to euthanasia, abortion, homosexuality, or affirmative action. ${ }^{13}$ Deferring to the Constitution in such cases may simply mean holding them open for future political resolution, and the constitutional interpreter should be sensitive to that possibility. Nonetheless, it may also be the case that faithful constitutional interpretation requires turning aside the preferences of current legislative majorities. The Constitution enshrines popular, not parliamentary, sovereignty.

All of this may seem to be begging a central question. Must even a faithful constitutional interpreter be committed to the language and intent of the founders? The short answer is yes. The implicit link between "language" and "intent" indicates the direction of the interpretive imperative. We readily recognize that we cannot be said to be interpreting a text if we disregard its language. But the language in the text does not emerge from the sea or drop from the sky, it was intentionally written by the authors of the text in order to communicate a message, to convey their thoughts to others. The text only exists as an object of interpretation if we assume that it embodies the intention of some actual author employing language. ${ }^{14}$ At a minimum, the choice of textual language reflects the intentions of an author that a faithful interpreter is bound to respect. But language is a means, not an end in itself. It should not be a fetish. ${ }^{15}$ We can only recognize the possibilities of malapropisms or irony if we are capable of distinguishing conventional language and authorial intent, and of privileging the latter over the former. ${ }^{16}$ We use language to convey intent. We interpret language in order to understand intent. It is a difficult interpretive question to determine what was actually intended by a particular piece of text, especially if the text is complex and the author relatively unknown. Likewise, it is a difficult interpretive question as to how best to go about determining textual intentions. In some cases, the interpreter may have nothing else available other than the text and an understanding of the usual conventions of the language. In other cases, the interpreter may have a richer set of materials on which to draw in the effort to understand what the author might have been intending to say. Good interpretation requires skill and judgment, but good interpretation is also oriented toward uncovering the meaning that words were meant to convey from the author to the reader.

A judge who strikes down a law as unconstitutional does so not on his own personal authority but on the authority of the
Constitution. He speaks authoritatively not for himself, but for the law-not as a constitutional actor, but as a constitutional interpreter. The text of the Constitution, in turn, only has authority as a consequence of its popular providence. It is our Constitution, because we have accepted it as our own. It lives, because we have breathed life into it.

Keith E. Whittington is an assistant professor of politics and John Maclean Jr. Presidential Preceptor at Princeton University.

\section{Endnotes}

1. The subgenre began with George Romero's classic, Night of the Living Dead. The 1968 Pittsburgh production is usually read as a postindustrial statement on "human smallness and ineffectuality." R.H. Dillard, "Night of the Living Dead: It's Not Like Just a Wind That's Passing Through," in American Horrors, ed. Gregory A. Waller (Urbana: University of Illinois Press, 1987), 27.

2. Anne Norton, Republic of Signs (Chicago: University of Chicago Press, 1993), 124.

3. See generally, Richard Hofstadter, The Idea of a Party System (Berkeley: University of California Press, 1969).

4. See generally, Mark A. Graber, Dred Scott and the Problem of Constitutional Evil (Princeton: Princeton University Press, forthcoming).

5. For a particularly good discussion of the theme of growth and change in John Marshall's opinion in McCulloch v. Maryland, see L.H. LaRue, Constitutional Law as Fiction (University Park: Pennsylvania State University Press, 1995), 70-92.

6. Alexander Hamilton, James Madison, and John Jay, The Federalist Papers, ed. Clinton Rossiter (New York: New American Library, 1961), No. 32, 197.

7. For one elaboration of that process, see Keith E. Whittington, Constitutional Construction (Cambridge: Harvard University Press, 1999).

8. See, for example, Rogers M. Smith, "The Inherent Deceptiveness of Constitutional Discourse: A Diagnosis and Prescription," NOMOS XL: Integrity and Conscience, ed. Ian Shapiro and Robert Adams (New York: New York University Press, 1998), 242-249.

9. The argument is developed at length in Keith E. Whittington, Constitutional Interpretation (Lawrence: University Press of Kansas, 1999).

10. I focus here on judiciary as the appointed interpreter of the Constitution. Others may also interpret the Constitution, including legislators, presidents and citizens. Judges are more familiar and highlight the relevant considerations more clearly, but the same concerns would apply to other interpreters. In any constitutional government of limited powers any interpreter potentially creates agency problems of the sort discussed in the text-elective credentials do not excuse legislators from abusing the trust of their limited offices.

11. On Federalist hagiography, see Michael Lienesch, New Order of the Ages (Princeton: Princeton University Press, 1988), 159-203. On "the founding as special dispensation," see Steven D. Smith, The 


\section{S Y M P O S I M}

Constitution and the Pride of Reason (New York: Oxford University Press, 1998), 31-47.

12. Cf., Robert H. Bork, The Tempting of America (New York: Free Press, 1990); Lino Graglia, "How the Constitution Disappeared," Commentary 81 (1986): 22.

13. This is not to say that the Constitution will not specify how judges should resolve a case raising those issues. The Constitution will indicate the appropriate decision-maker, even when it does not indicate the appropriate substantive decision.
14. For a recent general defense of intentionalist interpretation, see William Irwin, Intentionalist Interpretation (Westport, CT: Greenwood Press, 1999).

15. For a critique of Ronald Dworkin's textually oriented "semantic originalism," see Keith E. Whittington, “Dworkin's 'Originalism': The Role of Intentions in Constitutional Interpretation," Review of Politics 62 (2000): 5.

16. See also, Donald Davidson, "A Nice Derangement of Epitaphs," in Truth and Interpretation, ed. Ernest LePore (New York: Blackwell, 1986), 433-446. 